\section{More money for science in Reagan's last budget}

\section{Washington}

President Ronald Reagan delivered his final budget to Congress last week, a spending plan that seeks increased support for many areas of basic scientific research. Although it is tempting to view the lame-duck budget as 'dead-on-arrival' - because Congress and the Bush administration are certain to make changes - a complete overhaul of the $\$ 1,150,000$ million budget is virtually unthinkable, and many of the proposals contained in it are certain to be approved once the new fiscal year begins on 1 October.

The Reagan years have seen substantial increases in spending for research and development. In a speech last week introducing the proposed 1990 budget, White House Science Advisor William Graham pointed out with some pride that between 1982 and 1990 "federal support for basic research will have increased by 56 per cent in real terms", reaching $\$ 11,200$ million in 1990.

Graham used his budget remarks to criticize groups such as the National Academy of Sciences which have called for a stronger science adviser in the White House. He argued that "creating a science and technology 'tsardom' to direct what is to be done from the top down would be a disaster". Graham believes the best guidance for science comes from individuals doing research, and that a government's role is to support the best research.

The new budget calls for substantially greater spending on several big science projects; the National Aeronautics and Space Administration (NASA) budget requests $\$ 2,100$ million for the Space Station, the Department of Energy (DoE) will request $\$ 250$ million for continued development work on the Superconducting Super Collider (SSC), and the National Institutes of Health will be seeking $\$ 100$ million for the human genome project.

Although the space agency's budget request is considerably more than that for the previous year, NASA administrator James Fletcher says the budget is a lean one, with no room for alteration. He does not hide the fact that the space agency had sought considerably more money, but had its request scaled down by the White House Office of Management and Budget (OMB). Although OMB approved a request for new funds for $\mathrm{CRAF}$, the Comet Rendezvous/Asteroid Fly-by mission and its sister spacecraft Cassini, a planetary mission to Saturn, many prized projects have fallen by the wayside or been cut severely. There is no money for development of shuttle C, a cargo-carrying version of the space shuttle, and the Pathfinder advanced technology prog- ramme has been cut by more than half. In addition, OMB has decreed that $\$ 208$ million must be raised from the private sector to cover expected costs, an ambitious target with which the agency is not happy.

The requested rise of $\$ 927$ million for defence activities is an indication of the Energy Department's current preoccupation with getting the nuclear weapons programme back on track and bringing its ageing facilities into compliance with environmental regulations. Environmental safety and health programmes will also request significantly more money $\$ 124.6$ million in 1990 - but that is only a tiny fraction of the total cleanup cost at weapons facilities, estimated to be at least $\$ 50,000$ million.

In addition to requesting support for the SSC, DoE's budget also seeks construction funds for a 6-7 GeV Synchrotron Light Source at the Argonne National Laboratory in Illinois and the Compact Ignition Tokamak at Princeton, New Jersey. There is also a request for $\$ 27.6$ million for work on the human genome project, a $\$ 10$ million increase over that for 1989.

The National Science Foundation budget seeks $\$ 2,150$ million in 1990 , a 14 per cent increase. Science education continues to receive emphasis, with a total of $\$ 190$ million for precollege, undergraduate and graduate science education.

The National Institutes of Health (NIH) budget is scheduled for an additional 6.6 per cent for basic research. The total budget for $\mathrm{NIH}$ is set at $\$ 6,777 \mathrm{mil}$ lion, a modest 3.6 per cent rise over the current figure. This does not include a large increase in spending on research on AIDS, now listed as a separate item in the budget. The total request for federal AIDS activities within the Public Health Service is $\$ 1,600$ million.

Defence research, still accounting for nearly two-thirds of all federal spending on research, rises to $\$ 41,024$ million for the Department of Defense. The budget for the National Aerospace Plane is nearly $\$ 300$ million. The Strategic Defense Initiative request is for $\$ 5,800$ million, a $\$ 1,800$ million increase over 1989 . The Defense Advanced Research Projects Agency budget request is cut by nearly $\$ 166$ million to $\$ 1,121$ million.

Congressional budget committees will begin work in earnest on the budget once they have a clearer idea from Presidentelect Bush of what changes they can expect. But Albert Teich, one of the authors of a recent report for the American Association for the Advancement of Science on federal spending on research in the 1980 s, says there are not likely to be big changes judging by past experience. Teich points out that in 1981, Democrat Jimmy Carter's final budget was filled with signals that the transition to a new administration would bring significant changes when Republican Reagan took over. Those signals are not present today, suggesting that changes to the Reagan budget proposals will be at the margins rather than the core of the spending plans.

Joseph Palca

\section{UK meat research under threat}

\section{London}

BRITAIN's meat research could be severely curtailed next year by the threatened closure of the Bristol branch of the Agriculture and Food Research Council's Institute of Food Research, according to the Institution of Professional Civil Servants (IPCS), the union that represents more than half of the Bristol laboratory's 200 staff. The laboratory would be just the latest casualty of the government's policy to withdraw support from near-market research, for which it says industry should pay. The institute's director, Douglas Georgala, confirms that one of the three branches will close, but says no decision has yet been made as to which.

Many AFRC laboratories are suffering as a result of the reduction in contracts from the Ministry of Agriculture, Fisheries and Food, but the meat research laboratory has been hardest hit: its budget of $£ 3.2$ million is being halved over three years. The IPCS says efforts by the staff to become independent from government financing and secure contracts with industry are now being blocked: contracts between researchers and the Meat and Livestock Commission have been reduced from three years to two; contracts with industry and government through the LINK food-processing sciences programme will be restricted; and researchers are being prevented from submitting projects to FLAIR, the European food research programme. All these are signs, members of the Bristol laboratory believe, that their institute has been earmarked for closure.

Georgala says every effort is being made to help researchers secure contracts with outside bodies, but a temporary hold on international activities is necessary because the institute does not want to make commitments it may not be able to fulfill. He says the institute's activities will have to be cut back and is preparing a plan to implement cuts which will be presented to the AFRC in the next few months.

Closure of the Bristol laboratory will signify the end of meat research in Britain, says the IPCS, and the effect on the meat products industry, worth $£ 8,000$ million per annum, will be disastrous.

Christine McGourty 